\title{
TWÓRCY KULTURY W PROGRAMIE ROZGLOŚNI POLSKIEJ RWE (W PERSPEKTYWICZNYM SKRÓCIE)
}

\author{
Konrad W. TATAROWSKI (Uniwersytet Lódzki)
}

I.

Mówiąc o roli Rozgłośni Polskiej RWE w powojennej historii Polski, najczęściej podkreśla się jej znaczenie w wymiarze działalności informacyjnej i politycznej, mierzonej skutecznością burzenia monopolu informacyjnego komunistycznych mediów, a tym samym możliwości oddziaływania na opinię publiczną — wraz z ośrodkami decyzyjnymi - w kraju. Sukces, odniesiony przez monachijską Rozgłośnię, nie byłby jednak możliwy bez przyjęcia i konsekwentnego realizowania przez jej kierownictwo określonej strategii działania $\mathrm{w}$ eterze.

O założeniach polityki programowej RWE pisałem szerzej w innym miejscu ${ }^{1}$ w największym skrócie można by je ująć następująco: pogłębiona informacja o świecie współczesnym i wydarzeniach w kraju, ocalanie samoświadomości narodowej poprzez nawiązywanie do historii, tradycji, zasobów kultury, kształtowanie wzorców obywatelskiego myślenia - te szerokie założenia realizowane były w różnych audycjach, czę-

${ }^{1} \mathrm{~W}$ rozdziale Między wolnościa a odpowiedzialnościa. O zasadach polityki informacyjnej Rozgłośni Polskiej RWE, [w:] K.W. Tatarowski, Aksjologia i polityka w pisarstwie i działalności Jana Nowaka-Jeziorańskiego, Łódź 2010, s. 77-97. 
sto nic niemających wspólnego z bieżącą polityką. Znaczna część programu radiowego poświęcona była kulturze, szczególnie literaturze, ale także historii i szeroko pojętej wiedzy o współczesnym świecie.

W pierwszej „ramówce” programowej Głosu Wolnej Polski z maja 1952 roku² premierowe audycje kulturalne $\mathrm{w}$ tygodniowym programie zajmowały około $18 \%$ czasu antenowego (w tym audycje literackie - kąciki poetyckie, lektury książek „Na czerwonym indeksie" bądź programy z literaturą związane, uwzględniając również słuchowiska radiowe - około $11 \%$ ). Te wysokie wskaźniki z lat 50. i początku 60. później nie utrzymały się, choć tendencje spadkowe nie były drastyczne. W programie ramowym z połowy lat 60. udział audycji kulturalnych spadł do poziomu ok. 12\% — wzrosła za to znacznie ilość audycji muzycznych, w tym przeznaczonego dla młodzieży magazynu „Rendezvous at 6.10 ", prowadzonego od 1961 roku przez Jana Tyszkiewicza we współpracy z Zygmuntem Jabłońskiem, Barbarą Nawratowicz, Januszem Hewelem i — później Januszem Marchwińskim. Po zmianach w programie ramowym Rozgłośni w drugiej połowie lat 70. udział audycji kulturalnych ponownie wzrósł do ok. 15\%. Audycje literackie przez cały czas zajmowały około $10 \%$ czasu antenowego.

Największy regres pod tym względem nastąpił po zmianach, wprowadzonych do programu Rozgłośni na początku lat 90., kiedy to udział audycji kulturalnych w programie (zapowiadanym „na żywo”, live, praktycznie bez „powtórek”) spadł do poziomu poniżej $10 \%$, zaś literackich poniżej $7 \%$. Nawiasem mówiąc — to i tak dużo więcej niż w obecnych zaleceniach programowych Krajowej Rady Radiofonii i TV dla nadawców publicznych, którzy — jak się wydaje — bardziej myślą o konkurowaniu z prywatnymi nadawcami i ściąganiu pieniędzy z reklam niż o realizowaniu „misji” społecznej i kulturowej. A przecież spełnianie owego posłannictwa stanowiło o sensie działalności i ostatecznym sukcesie Rozgłośni Polskiej RWE. Znamienna jest opinia, wypowiedziana przez Jerzego Giedroycia - który do entuzjastów monachijskiego radia nigdy się nie zaliczał — po likwidacji Rozgłośni w 1994 roku:

Zamknięcie Rozgłośni Polskiej RWE jest zamknięciem walki o niepodległość Polski, prowadzonej przez naszą emigrację polityczną. W tej walce radio odegrało czołową rolę we wszystkich dziedzinach, było ono drogowskazem nie tylko dla wszystkich działań niepodległościowych w Kraju ale również odegrało wielką rolę w dziedzinie kulturalnej. Dzięki temu zniewolony kraj mógł się czuć związany z demokratyczną Europą i nie ulec zsowietyzowaniu. Trudno też sobie wyobrazić, czym byłaby nasza emigracja bez Wolnej Europy. Rozbudowana sieć tzw. freelancerów była ogromną pomocą, również materialną, dla pisarzy, publicystów czy aktorów ${ }^{4}$.

O szerokim zakresie współpracy Rozgłośni ze środowiskami emigracyjnymi, od początku jej działalności, świadczy wypowiedź jej pierwszego dyrektora, Jana Nowaka:

W samej Anglii żyło w 1952 r. 755 pisarzy, dziennikarzy, uczonych i aktorów. Na kon-

${ }^{2}$ Ramowy program Rozgłośni Polskiej RWE z lat 1952-1993 szerzej omawiam w: K. W. Tatarowski, Literatura i pisarze w programie Rozglośni Polskiej Radio Wolna Europa, Kraków, 2005, s. 69-81.

3 Pojęcie „misji” przywołuję w znaczeniu: „odpowiedzialne zadanie do spełnienia: misja kulturalna, naukowa, społeczna”; za: Stownik języka polskiego, t. 2, Warszawa, 1988. Warto jednak zwrócić uwagę, że zwłaszcza w pierwszym okresie działalności RWE wiązało się też owo pojęcie z innym jego znaczeniem: ,posłannictwa”.

4 „Przesłanie Jerzego Giedroycia” odtworzone z taśmy magnetofonowej podczas Koncertu Pożegnalnego RWE; Pożegnanie RWE, Poznań, 20-21 czerwca 1994. Dokumentacja, skrypt Stowarzyszenia Pracowników Rozgłośni Polskiej RWE, oprac. A. Rosenbusch, s. 54. 
tynencie europejskim nasza lista ewidencyjna obejmowała 389 nazwisk, w Stanach Zjednoczonych 83, w innych krajach 105. Ponad 100 tysięcy Polaków, z czego 40 tysięcy żyjących w Londynie, pozwoliło wprowadzić rozmaitość głosów, transmitowanie uroczystości narodowych i wszelkich przejawów życia zbiorowego ${ }^{5}$.

\section{II.}

Realizacja wspomnianych założeń programowych możliwa była od początku działalności Głosu Wolnej Polski RWE dzięki właściwemu doborowi zespołu dziennikarskiego i realizacyjnego przez Jana Nowaka-Jeziorańskiego. Wystarczy przypomnieć, iż w pierwszych latach działalności w ekipie monachijskiej Rozgłośni znaleźli się między innymi: przedwojenny kierownik „Lwowskiej Fali”, Wiktor Budzyński, dyrektor radia w Poznaniu, Zdzisław Marynowski, znany reporter sportowy, Wojciech Trojanowski, wybitny reżyser teatralny i radiowy, Wacław Radulski, znakomici kompozytorzy — Roman Palester i Jan Markowski, do których na początku lat 60. dołączył Alfred Schütz, pisarz i przedwojenny radiowiec, Wiktor Trościanko, historyk Wiktor Sukiennicki, pisarze: Włodzimierz Sznarbachowski, Kazimierz Sowiński i Bronisław Przyłuski, z młodszej zaś generacji: Tadeusz Nowakowski, Gustaw Herling-Grudziński, Tadeusz Chciuk-Celt.

Od samego początku z Rozgłośnią współpracowali, mieszkający wówczas w Nowym Jorku: Kazimierz Wierzyński, Jan Lechoń i Józef Wittlin. Pierwszy z nich, niezwykle aktywny i często obecny na antenie radiowej w różnych audycjach i dyskusjach literacko-artystycznych, między 7 lutego 1962 roku a 6 stycznia 1965 roku czytał w cotygodniowych odcinkach swój Pamiętnik poetycki — niezwykle cenne źródło dla badaczy XX-wiecznej poezji polskiej. Słuchacze Wolnej Europy jeszcze przed publikacjami książkowymi (i tak zresztą niedostępnymi w kraju) słuchali jego wierszy z Czarnego Poloneza i wcześniejszych tomików w stałych audycjach poetyckich i literackich. Ostatni wiersz, Na śmierć Jana Palacha, przedstawił Wierzyński na radiowej antenie 30 stycznia 1969 roku — dwa tygodnie później zmarł.

Również Jan Lechoń współpracował z Rozgłośnią aż do tragicznego końca. Najlepiej świadczy o tym fakt, iż poprowadzona przez niego Dyskusja o teatrze polskim na emigracji z 25 czerwca 1956 roku z udziałem Mariana Hemara, Ziemowita Karpińskiego i Józefa Wittlina została wyemitowana... dwa tygodnie po jego śmierci (zmarł 8 czerwca 1956). Brał on udział w licznych audycjach wspomnieniowych (w ramach cyklu „Głos Wolnych Pisarzy"), był też autorem jasełek i innych form słuchowiskowych. Między innymi — Pastorałka ukazała się na radiowej antenie 25 grudnia 1953 roku Żaden badacz jego twórczości nie może przejść obojętnie obok niektórych jego wypowiedzi radiowych — np. w dyskusji O roli natchnienia w poezji z 2 grudnia 1953 roku'.

Stałym uczestnikiem owych rozmów, nadsyłanych z Nowego Jorku, obok Lechonia i Wierzyńskiego był też Józef Wittlin, który również od kwietnia 1958 roku do lutego 1960 roku w trzeci piątek każdego miesiąca zagospodarowywał piętnastominutowy „Kącik poetycki”.

III.

Londyńskim biurem RWE — w którym powstało wiele audycji kulturalnych i literackich — kierował Leopold Pobóg-Kielanowski, reżyser i organizator życia teatralne-

\footnotetext{
${ }^{5}$ J. Nowak-Jeziorański, Wojna w eterze, Kraków 2006, s. 81.

${ }^{6}$ Tę, i inne wypowiedzi Lechonia, opublikowałem w cyklu „Z Taśmoteki Rozgłośni Polskiej RWE", Tygiel Kultury 1997 nr 6-7, s. 76-79.
} 
go na emigracji, autor wielu audycji radiowych, poświęconych rozwojowi teatru, a także filmu na Zachodzie, oraz rozmów z pisarzami i politykami emigracyjnymi, między innymi z Mieczysławem Grydzewskim z 26 lipca 1953 roku$^{7}$. Wiersze mieszkającego wówczas w Londynie Stanisława Balińskiego wypełniły dwa pierwsze „Kąciki poetyckie", 4 i 11 maja 1952 roku Występował on także w roli dziennikarza, prowadzącego rozmowy z innymi autorami (np. z Józefem Łobodowskim w październiku 1953).

Tymon Terlecki — organizator „Dyskusji okrągłego stołu” — był też autorem scenariuszy ponad dwudziestu słuchowisk, stanowiących radiowe adaptacje utworów pisarzy zachodnich, staropolskich XVII-wiecznych misteriów wielkanocnych, bądź polskich klasyków, jak Juliusz Słowacki czy Wacław Potocki. Wacław Zbyszewski co tydzień gościł na antenie jako autor felietonów Wędrówki po Europie, nadawanych przez ponad dwadzieścia lat od września 1958 roku, zaś generał Marian Kukiel ze swoimi gawędami o „Sylwetkach z przeszłości” i „Sylwetkach z moich czasów”, nadawanymi od początku 1958 roku do połowy roku 1966. Częstymi uczestnikami audycji historycznych byli Lidia i Adam Ciołkoszowie.

Warto tu dodać, że problematyka historyczna była na antenie RWE szczególnie preferowana. W takich audycjach jak „Współczesna historia Polski” (w latach 19711985) występowali między innymi: Paweł Zaremba, Andrzej Pomian, Stefan Korboński, Wacław Jędrzejewicz, czy historyk literatury, Jerzy Krzyżanowski.

Zygmunt Nowakowski z Londynu nadawał na antenie „Pogadanki teatralne” w 1954 roku i gawędy historyczno-literackie w cyklu „Słowo polskie nasz chleb niepowszedni" (w latach 1956-1960). On też — 5 marca 1953 roku — pięknym Listem do Krakowa zainicjował cykl audycji „List do Polski”, w których występowali potem inni emigracyjni pisarze.

Stałą uczestniczką radiowych dyskusji „okrągłego stołu”, a nieco później — po odejściu z Rozgłośni Gustawa Herlinga-Grudzińskiego w 1956 roku — autorką cotygodniowych komentarzy kulturalnych była Maria Danilewicz-Zielińska. Współpracę w Głosem Wolnej Polski podjęły też redaktorki „Wiadomości”: Stefania Kossowska, Herminia Naglerowa i Stefania Zahorska oraz Jan Bielatowicz, Józef Bujnowski i Juliusz Sakowski.

Marian Hemar był autorem cotygodniowych satyryczno-polityczno-lirycznych „Kabaretów”, obecnych na antenie od 1953 roku aż po koniec lat 60. Towarzyszyli mu w nich Włada Majewska (która — jak pisał Jan Nowak-Jeziorański — „była w jednej osobie aktorką, śpiewaczką, reżyserem i sekretarką. Do tego jeszcze zręczną dyplomatką, łagodzącą większe i mniejsze konflikty między nami a polskim Londynem"8), a także, również pochodzący ze Lwowa Jerzy Kropiwnicki i Tadeusz Kryska-Karski. Londyńskie biuro RWE dostarczało w pierwszych dziesięcioleciach działalności Rozgłośni 14\% całego programu ${ }^{9}$ - w zdecydowanej większości o charakterze kulturalnym.

Trzecim emigracyjnym ośrodkiem, przesyłających wiele materiałów do audycji literackich Rozgłośni polskiej RWE, był Paryż. Teksty publikowane w „Kulturze”, a także książki, wydawane przez Instytut Literacki, były omawiane bądź przytaczane na antenie od początku działalności RWE. Pierwszymi paryskimi współpracownikami RWE byli pomijając Gustawa Herlinga-Grudzińskiego, który był etatowym pracownikiem RWE do 1956 roku, a później współpracę z Rozgłośnią kontynuował — Ludwik Mieroszewski oraz Maria Czapska i Konstanty Jeleński, którzy nadsyłali korespondencje do audycji

\footnotetext{
${ }^{7}$ Transkrypcja tej rozmowy: Tygiel Kultury $1996 \mathrm{nr} 2$.

${ }^{8}$ J. Nowak-Jeziorański, Wojna w eterze, s. 512.

${ }^{9}$ Tamże.
} 
Romana Palestra „Okno na Zachód”10. Częstym gościem audycji, poświęconych sprawom zbrodni katyńskiej, ale także literatury i sztuki, był Józef Czapski. Krajowe nowości książkowe w latach 1961-1968 omawiał na antenie Jerzy Stempowski ${ }^{11}$.

IV.

Najobfitsza lista radiowych dokonań należy niewątpliwie do Tadeusza Nowakowskiego $^{12}$, który związany był z Rozgłośnią od początku do końca jej istnienia, przez ostatnie kilka lat — już po przejściu na emeryturę — prowadząc cotygodniowe gawędy „Przy kawiarnianym stoliku”. Był on autorem pierwszego w historii Głosu Wolnej Polski słuchowiska Witaj jutrzenko swobody" (w reżyserii Wacława Radulskiego), w dniu inauguracji działalności stacji, 3 maja 1952 roku. Ten erudyta o szerokich horyzontach, znakomity pisarz, doskonale radził sobie z warsztatem radiowego żurnalisty — chociaż, jak zauważył Jan Nowak-Jeziorański — „Nowakowski nie lubił Olsztyńskiego [radiowy pseudonim pisarza — przyp. KWT]. Uważał, że praca radiowa to chałturzenie, które szkodzi reputacji pisarza Nowakowskiego"13. Potrafił wcielić się w rolę sprawozdawcy i reportera (2 czerwca 1953 roku relacjonował uroczystości koronacyjne Elżbiety II, później pełnił rolę reportera papieża Jana Pawła II), był autorem wywiadów z politykami i ludźmi kultury czy wreszcie redaktorem, prowadzącym przez wiele lat magazyn „Panorama dnia”. Jako pisarz najpełniej realizował się na antenie radiowej w roli autora słuchowisk radiowego „Teatru Wyobraźni”. Scenariuszy swoich słuchowisk nigdy nie publikował — a zebrałaby się z nich dość gruba książka.

Autorem wielu słuchowisk Teatru Wyobraźni RWE był też Wiktor Trościanko, znakomity publicysta $\mathrm{z}$ dużym temperamentem polemicznym, wieloletni autor audycji „Odwrotna strona medalu”, twórca słuchowisk historycznych — między innymi wizyjnego Mocniejsze niż historia z 3 maja 1955 roku, w którym narratorem jest ,duch dziejów”, oprowadzający słuchaczy po historii Polski, od Piastów aż po utratę niepodległości. Kilka interesujących słuchowisk historycznych, nadawanych na antenie w konwencji reportażu lub rozprawy sądowej, przygotował też — niezwykle ciepło wspominany przez radiowych przyjaciół ${ }^{14}$ - Czesław Straszewicz, który przyjechał do Rozgłośni z Urugwaju w 1954 roku i przepracował w niej siedem lat. Autorem kilku radiowych „,jednoaktówek” był Marian Hemar; bogata i zróżnicowana była twórczość słuchowiskowa Tymona Terleckiego, Zygmunta Jabłońskiego czy Henryka Rozpędowskiego ${ }^{15}$.

Repertuar słuchowisk Rozgłośni Polskiej RWE nie ograniczał się do autorów polskich - sięgano też do adaptacji tekstów pisarzy zachodnich bądź rosyjskich. Można tu na przykład przypomnieć radiofonizację sztuki Aleksandra Sołżenicyna, Świeca na wietrze, nadanej w programie Rozgłośni Polskiej 15 czerwca 1974 roku. Była to światowa prapremiera tego utworu, napisanego przez autora Oddziatu chorych na raka

${ }^{10} \mathrm{O}$ współpracy autorów związanych z „Kulturą” z R.P. RWE szerzej piszę w: Paryska „Kultura” wobec R.P. RWE. Konflikty $i$ wspótpraca, [w:] K. W. Tatarowski, Niezależna literatura i dziennikarstwo przed 1989 rokiem. Idee - ludzie - spory, Łódź, 2016, s. 51-65.

${ }^{11}$ J. Stempowski, Felietony dla Radia Wolna Europa, oprac. J. Timoszewicz, Warszawa 1995.

${ }^{12}$ Radiowe dokonania T. Nowakowskiego i innych wymienionych w tekście autorów obszerniej omawiam w: K. W. Tatarowski, Literatura i pisarze w programie Rozgłośni Polskiej Radio Wolna Europa, Kraków 2005.

${ }^{13}$ J. Nowak-Jeziorański, Wojna w eterze, s. 495.

${ }^{14}$ Zob. tamże, s. 496-498; T. Nowakowski, Aleja dobrych znajomych, Londyn 1968, s. 185-195.

15 Słuchowiska radiowe RWE omawiam szerzej w rozdziale Radiowy „Teatr Wyobraźni”, Rozgłośni Polskiej RWE, [w:] Literatura i pisarze, s. 251-291. 
w 1960 roku. Miała być wcześniej wystawiona w moskiewskich teatrach, ale do scenicznej premiery nie doszło. Sztukę Sołżenicyna przełożył i zradiofonizował Leopold Kielanowski, a zrealizował Jacek Machniewicz.

Do arcydzieł sztuki radiowej należałoby zaliczyć reportaże historyczne Wojciecha Trojanowskiego, „latającego reportera”, który pracował w Rozgłośni do 1970 roku, odnajdując atrakcyjne tematy $\mathrm{w}$ różnych, również egzotycznych częściach świata, a także podążając z mikrofonem śladami polskiej historii. Między innymi jest on autorem reportażu z Reggio Emilia o pierwszym wykonaniu Mazurka Dąbrowskiego w lipcu 1797 roku (Ta żotnierska piosenka z 23 lipca 1962) ${ }^{16}$.

O działalności reporterów RWE pisał Jan Nowak-Jeziorański:

Owocem podróży Trościanki do Egiptu była seria słuchowisk „Kamienne dno czasu”, Jabłoński po zwiedzeniu Elby nadał słuchowisko o „Mały kapral na Elbie”, Jerzy Kaniewicz (Mieleszko) wędrował śladami Czarnieckiego po Danii, Nowakowski śladami Mickiewicza i Słowackiego po Paryżu, Rzymu, Bolonii i Mediolanie. Rozpędowski nagrywał reportaże z Ziemi Świętej [...]. Stypułkowska szukała śladów Sienkiewicza w Vevey nad Lemanem, gdzie wielki pisarz zakończył życie. Palester i Wolski (Tański) jeździli na festiwale do Wenecji i do Cannes. [...] Po drugiej stronie oceanu Wantuła i Śmiałowski nagrywali reportaże w rezerwatach Indian i w najstarszych osiedlach polskich w Teksasie o nazwach „Panna Maria” i „Częstochowa” oraz w kaszubskich wioskach w Kanadzie. [...] Jabłoński i Zbyszewski odwiedzili polską osadę Adampol nad Bosforem, która powstała po Powstaniu Listopadowym i przetrwała od tamtych czasów aż do dziś, jak zdjęcie w starym albumie ${ }^{17}$.

\section{V.}

Warto zwrócić uwagę na kwestię „strategii” programowo-kulturalnej Rozgłośni Polskiej, realizowanej od samego początku. Z jednej więc strony adresowano audycje literackie do ludzi wykształconych, zapewniając im „pokarm duchowy” w postaci rodzimej literatury „Z najwyższej półki”, otwierając „Okno na Zachód” (tytuł jednej z pierwszych audycji kulturalnych RWE) na to, co się działo w europejskim i światowym kinie, teatrze, w życiu artystycznym i literackim. Towarzyszyły temu przekłady tekstów twórców zachodnich bądź wybitnych emigrantów z Rosji i Europy Środkowowschodniej, ich omówienia bądź adaptowanie do potrzeb „Teatru Wyobraźni”.

Z drugiej zaś strony audycje kulturalne RWE adresowane były do szerokich rzesz słuchaczy - wystarczy tu wymienić radiowe wodewile i „kabarety polityczne” Wiktora Budzyńskiego czy wspomnianego wcześniej Mariana Hemara. Powieści radiowe, Rodzina Kubiczów Aleksandry Stypułkowskiej (Jadwigi Mieczkowskiej) i $W$ czterech ścianach Tadeusza Chciuka-Celta (Michała Lasoty), nadawane od początku działalności Rozgłośni, wyprzedziły o cztery lata popularnych Matysiaków, których Polskie Radio zaczęło nadawać w roku 1956.

Budzyński był twórcą pierwszego spektaklu radiowego Teatru Wyobraźni, zapisanego w ramówce programowej pod groźnie brzmiącym tytułem Fighting Theatre no. 1 (Preclarka z Pohulanki, nadanego 5 czerwca 1952 roku w reżyserii Wacława Radulskiego). Pojawiły się w nim postaci — na przykład pani Kminkowej — które potem przez wiele lat bawiły słuchaczy Głosu Wolnej Polski w cotygodniowych „Podwieczorkach przy mikrofonie".

\footnotetext{
${ }^{16} \mathrm{O}$ radiowej twórczości W. Trojanowskiego piszę szerzej w mojej książce Niezależna literatura i dziennikarstwo przed 1989 rokiem.

${ }^{17}$ J. Nowak-Jeziorański, Wojna w eterze, s. 505.
} 
Należy też podkreślić, że wszyscy wymienieni autorzy występowali na radiowej antenie nie tylko w roli autorów wierszy, prozy artystycznej i scenariuszy słuchowisk. Byli też komentatorami i recenzentami sztuki, spektakli teatralnych i filmowych, wspominali okres Polski niepodległej i śledzili z uwagą bieżące życie kulturalne w Polsce, w środowiskach emigracyjnych i w krajach zachodnich.

Wielu z nich — jak na przykład Wiktor Trościanko, autor audycji „,Druga strona medalu”, Tadeusz Chciuk-Celt w audycjach dla wsi, Gustaw Herling-Grudziński w roli autora „Listów do młodego komunisty” czy Tadeusz Nowakowski, jako redaktor „Panoramy Dnia" - wchodziło w rolę komentatorów bieżących wydarzeń politycznych i spraw, wykraczających poza teren sztuki i literatury. Inteligencja i erudycja, wysoka kultura językowa ich wypowiedzi, podobnie zresztą jak i innych komentatorów politycznych R.P. RWE - towarzyszące koniecznej często złośliwości i ironii — sprawiały, iż dostarczali słuchaczom nie tylko uciechy, że ktoś „wygarnia” komunistom prawdę, ale również pokazywali, jak to robić, nie zniżając się do poziomu „pyskówki” i kłótni. Ta swoista „elegancja stylu", rzeczowość i sposób argumentacji, odwołujący się do konkretów i faktów, stanowiły znakomitą lekcję kultury politycznej — jakże odległej od wzorców szerzonych niegdyś w „Trybunie Ludu”, a i dziś niekiedy w największych stacjach telewizyjnych.

Zapewniali oni od samego początku wysoki poziom radiowego programu - zarówno ze względu na treści w nim zawarte, jak i na formę i sposób ich radiowej realizacji. Jak pisał pod koniec lat 50. uciekinier z Polski, Henryk Rozpędowski, który monitorował program na prośbę Jana Nowaka-Jeziorańskiego:

Uderzała staranność i czystość nagrań. Dwa słyszane wtedy słuchowiska, Farma zwierzęca według Orwella i adaptacja tekstu Kiplinga w reżyserii Wacława Radulskiego, były majstersztykami radiowej roboty, inwencji i wyobraźni. Żadnych kiksów w zmianach i przenikaniu sekwencji, bezbłędna operacja planami, czyste dźwięki, doskonale wspierająca treść muzyka, rytm, dynamika, ekspresja. Dobry przykład wysokiego radiowego rzemiosła, kultury i smaku. We wszystkich audycjach techniczna perfekcja. Mój ty Boże - pomyślałem - ileż w tym pracy. [...] Leci ten wypieszczony produkt w eter i napotyka warkot zagłuszarek ${ }^{18}$.

\section{VI.}

W późniejszych latach do zespołu RWE dochodzili inni znani publicyści i ludzie ze świata kultury i sztuki. W latach 60. Henryk Rozpędowski, Jerzy Kaniewicz, Piotr Guzy, Czesław Dobek. Na początku lat 70. Włodzimierz Odojewski, który — po odejściu na emeryturę Romana Palestra — redagował programy kulturalne Rozgłośni, korzystając ze współpracy pisarzy i krytyków literackich z kraju. Od drugiej połowy lat 70. coraz więcej miejsca na antenie zajmują teksty powstałe w „drugim obiegu” wydawniczym w Polsce $^{19}$. Kolejna dekada — wraz z objęciem kierownictwa Rozgłośni Polskiej RWE przez Zdzisława Najdera — przyniosła napływ dziennikarzy i ludzi kultury z kraju, między innymi etatowe zatrudnienie w monachijskiej Rozgłośni przyjął Jacek Kaczmarski, zaś częstymi uczestnikami audycji kulturalnych byli przebywający na Zachodzie pisarze i eseiści: Jakub i Wojciech Karpińscy, Barbara Toruńczyk, Ewa Bieńkowska, Krzysztof Rutkowski, Bronisław Wildstein i wielu innych.

${ }^{18}$ H. Rozpędowski, Byt chamsin, Londyn 1994, s. 62.

${ }^{19}$ Szerzej piszę o tym w artykule Literatura niezależna i prasa podziemna w Rozgłośni Polskiej RWE, [w:] Czas Bibuly 1. Mechanizmy - ludzie - idee, red. R. Wróblewski, Wrocław 2013, s. 23-36. 
Poczynając od drugiej połowy lat 80., coraz częściej w audycjach monachijskiej Rozgłośni pojawiają się nie tylko teksty publikowane w „drugim obiegu” wydawniczym w Polsce, ale również ich autorzy, mieszkający w kraju. Wolna Europa z wolna traci charakter rozgłośni emigracyjnej — po upadku muru berlińskiego i otwarciu biura w Warszawie jesienią 1989 roku stając się częścią krajowego ładu informacyjnego. Ale aż do końca działalności Rozgłośni w czerwcu 1994 roku nie uległa zmianie struktura programu wraz z jego zasadniczym przesłaniem, które można by zilustrować strofą Czesława Miłosza z Traktatu moralnego:

\author{
Lawina bieg od tego zmienia, \\ Po jakich toczy się kamieniach, \\ I, jak zwykł mawiać już ktoś inny, \\ Możesz, więc wpłyń na bieg lawiny.
}

Rozgłośnia Polska RWE, w miarę swoich możliwości, wpływała na zmianę biegu toczącej się — przez dziesiątki lat wydawało się przecież, że w sposób nieuchronny — lawiny systemu politycznego, narzuconego społeczeństwu polskiemu przemocą i przyniesionego zza wschodniej granicy. Wpływała — kontynuując poetycką przenośnię szlifując owe kamienie, czyli przeciwstawiając się, jak to określał Aleksander Wat, „pierekowce dusz” i sowietyzacji umysłów mieszkańców Polski.

\title{
LITERATURA
}

L. Gawlikowski, Pracownicy Radia Wolna Europa. Biografie zwykte i niezwykłe, Warszawa 2015;

J. Nowak-Jeziorański, Wojna w eterze, Kraków 2006;

T. Nowakowski, Aleja dobrych znajomych, Londyn 1968;

Pożegnanie RWE, Poznań, 20-21 czerwca 1994. Dokumentacja, skrypt Stowarzyszenia Pracowników Rozgłośni Polskiej RWE, oprac. A. Rosenbusch;

H. Rozpędowski, Byt chamsin, Londyn 1994;

J. Stempowski, Felietony dla Radia Wolna Europa, oprac. J. Timoszewicz, Warszawa 1995;

K. W. Tatarowski, Literatura i pisarze w programie Rozglośni Polskiej Radio Wolna Europa, Kraków 2005;

—, Aksjologia i polityka w pisarstwie i działalności Jana Nowaka-Jeziorańskiego, Łódź 2010;

—, Niezależna literatura i dziennikarstwo przed 1989 rokiem. Idee - ludzie - spory, Łódź 2016;

V. Wejs-Milewska, Radio Wolna Europa na emigracyjnych szlakach pisarzy: Gustaw Herling-Grudziński, Tadeusz Nowakowski, Roman Palester, Czesław Straszewicz, Tymon Terlecki, Kraków 2007;

—, Wykluczeni - wychodźstwo, kraj, Białystok 2012.

\section{PROMOTERS OF CULTURE IN THE PROGRAMMES OF THE POLISH SECTION OF RADIO FREE EUROPE: AN INTRODUCTION}

The article provides concise information concerning writers, journalists and historians creating literary and cultural programmes broadcast by the Polish Section of Radio Free Europe in the years 1952-1994. It highlights the cultural, artistic and educational activity of the Munich radio station and its role in preserving national and historical collective memory of the citizens of the Polish People's Republic, which contributed to the fall of communism in Poland.

KEY WORDS: Radio Free Europe; Polish Section of Radio Free Europe; Polish diaspora after Second World War; Polish cultural life in exile. 